\title{
Significance of Inter Religious Dialogue for the Christian Community Today
}

\author{
Jacob Kavunkal SVD \\ Yarra Theological Union/University of Divinity, Melbourne, Australia \\ Correspondence: Jacob Kavunkal, Yarra Theological Union, 98 Albion Road, Box Hill, Vic 3128, Australia.
}

Received: February 16, 2016

Accepted: February 24, 2016

Available online: March 1, 2016

doi:10.11114/ijsss.v4i3.1430

URL: http://dx.doi.org/10.11114/ijsss.v4i3.1430

\begin{abstract}
The theological account of Christian service to fellow humans had customarily been couched in the language of salvation presumed to be fully available only through the Christian churches. This article argues how salvation is God's work and is available to all. The specific Christian vocation is to continue the mission of Jesus Christ which was bringing the divine reign. The article goes on to show that in the contemporary world this can be achieved only through the collaboration of the followers of all religions which in turn is built on Inter Religious Dialogue.
\end{abstract}

Keywords: bible, mission, divine reign, interreligious dialogue, transformation

\section{Introduction}

Arguably, there is no dearth of literature on Inter Religious Dialogue (IRD). Most of it, however, reflects either a spirit of Christian superiority, or an attitude of resignation, "since nothing else is possible." On the other hand, our age with its prevailing reality of globalization accompanied by instant communication and mass migration, has effected in many respects a vision of one world, along with its characteristic religious pluralism. Equally, we experience also the dividing walls of violence, poverty and injustice. This is a great challenge for the Christians in the context of their call to be witnesses of the good news of Jesus Christ, "the arrival of the acceptable year of the Lord." In the following pages it is shown how the Christian response to this context is engagement in IRD which, in fact, has to become the primary expression of Christian mission today.

\subsection{The Good News}

Though the four evangelists differ in their perspectives, they converge in their presentation of the good news. Mark the first one to write the gospel, begins by stating how the good news began to be (1.1) ${ }^{\mathrm{i}}$ and how it comes to be continued (16:7), with the description of the ministry of Jesus in between. The ministry itself is the focal point and it is a narrative of how through his ministry Jesus ushers in the divine reign (1:14-15). Mathew concurs with Mark by repeating almost the same words (4:17). Luke, the evangelist whose purpose was to make a "systematic narration of the events" (1:3), dwells on how God's reign is brought on earth by Jesus (4:18-21). In the second part of the Lukan narrative, the Acts of the Apostles, Peter summarizes the entire mission of Jesus as his "going about doing good" (10:38). The fourth evangelist John, though sparse in the use of the terminology of the divine reign, nevertheless is faithful to the reality in so far as he states that the mission of Jesus was manifesting the deeds of light, "that it may be clearly seen that his deeds have been wrought in God" (3:21, 16-21).

Jesus began his ministry by proclaiming the arrival of the acceptable of year of the Lord, which was good news to the poor. Jesus, above all, had an intimate experience of God that others did not have, and this he tried to share with all, with his followers and with others, with all its implications, being compassionate to one another, leading to communion. The salvation that Jesus spoke about was a transformation of life on earth with right relationship with the neighbour and with God (see, f.i., Lk 10:25-37; 19:1-10; Mt 25:31-46, and others).

\subsection{Later Developments}

Though Jesus' primary message was the good news to the poor, he spelt it out through the prophetic words of Isaiah 61.1-2, sight to the blind, ability to walk to the lame, setting at liberty the captives - in one word - concern for the neighbour (Mt 25:31-40). The religious system transformed it to a discourse of heaven and hell, punishment and reward, an after-death reality. 
The religious establishment interpreted the mission of Jesus as atonement, and the mission of the church as that of saving souls for whom Jesus had paid by his blood, a salvation that is confined only to the church. Hence Christian mission was primarily to bring as many as possible into the church. Salvation itself was interpreted as an otherworldly reality that can be gained only within the church. Naturally the church's mission was seen mainly as an exercise of church planting and church expansion.

\section{The Christian Call}

Vatican $\mathrm{II}^{\mathrm{ii}}$ made a corrective move by insisting how all have a common origin and a common destiny (NA 1$)^{\mathrm{iii}}$ and exhorted Catholics to enter prudently and lovingly into dialogue with the followers of other religions and thus "acknowledge, preserve, and promote the spiritual and moral goods found among these men, as well as the values in their society and culture" (NA 2). In this the Council was only upholding the biblical revelation that affirms the creation of all humans by God into God's own image and with whom God entered into an eternal covenant (Genesis 1.26-28). Evangelist John made this vision as the opening theme of the Gospel. The Word through whom God created all and who enlightens all became flesh (1:1-4,9). All revelation and religious knowledge is traced to the same Mystery. There is no reason to make a distinction between natural and supernatural revelation and natural and revealed religions in so far as every religious activity is the response to the same revealing Mystery.

However, the bible insists equally how right from the beginning God calls individuals and peoples for a specific service. Thus, Abraham is called to become a blessing to all (Genesis 12:3). In the same spirit Israel is called to serve as a light to the nations (Isaiah 42:6; 49:6). In fact, right before God makes the covenant with Israel, they are told that they are made his people so that they are to be a kingly, priestly and holy nation (Exodus 19:5-6). All the three roles remind them of their vocation to be of service to the rest of the nations (Ross, 2012: 89-95).

This same call is continued through the formation of the new community of the disciples of Jesus Christ. The Matthean inaugural sermon unmistakably points to their service as the salt and light to the world (Mt 5:13-16). Even the post-resurrection mission mandate is linked to this role, by including the teaching of "all that I have commanded you" (Mt 28:20). There have to be communities of the disciples of Jesus in every culture precisely for serving as the salt, light and leaven (Mt 13:33). Hence the message of the Kingdom is accompanied by the formation of the new community (Mk 1:15-20; 3:13-14). This role of the Christian community today, as the Vatican Council declared, is fulfilled through IRD. Not only the Catholic Church, but other Christian churches too made IRD a priority (WCC, 1979).

In the past Christian theology in general was trying to explain away other religions, with the theories of preparation, fulfilment, seeds of the Word, etc., always holding that Christianity is the only God-willed religion. Rather, we Christians have to ask ourselves what is the service that we can render to a world in which God is actively involved, always rooted in the Christian call to service. The church now regards with esteem the believers of all religions, appreciating their moral and spiritual commitment. As Pope Francis has pointed out, "there have been so many events, initiatives, institutional or personal relationships with non-Christian religions in these fifty years, since the publication of Nostra Aetate" (2015). The Pope characterized these as expressions of the church's hope that all believers in God would favour friendship and unity between peoples. Indifference and opposition have changed to collaboration and benevolence. "Former enemies and strangers, we have become friends and brothers" (Francis, 2015).

Discipleship does not adopt a "one-among-the many" attitude, but the call to follow the Word Incarnate in his mission of realizing the divine reign. As John Paul II wrote to Cardinal Cassidy on the occasion of the XIII International Meeting of Peoples and Religion, "we must all be bolder on this journey, so that the men and women of our world, to whatever people or belief they belong, can discover that they are children of the one God and brothers and sisters to one another" (John Paul, 2001).

The Christian call, Pope Francis reminds us, is to be "missionary disciples" (2013, n.120). However, this does not mean that we reach out to the followers of other religions only as raw material for church growth, but as collaborators in realizing the divine reign. Our call is not to proselytize, but respect others' beliefs and thus inspire others through Christian witness so as to grow together through communication. In this the Christian community has an important role to serve as the leaven.

\section{Inter Religious Dialogue}

Right at the beginning I must caution that IRD is not an entity but a process of becoming. It is a process of becoming a community of persons, respectful and respecting, transforming and transformed, renewing and renewed. This allows the process of IRD a certain amount of spontaneity as well as open-endedness. It acknowledges the need to turn to each other and together to the ground of our being, to the goal of our existence. Thus, it is permeated by a sense of radical transcendence and at the same time down to earth immanence in so far as it is primarily directed to the horizontal level 
of understanding and acceptance. It is through and through guided by the mandate to "seek first the divine reign" (Mt 6:33).

IRD is a symbol of the Kingdom, to which we are pilgrimaging: it is a "diffuse symbol" (Arbuckle, 2010: 25), i.e. its meaning depends on the different contexts of the dialogue process: faith, religion, and commitment to transformation -

Leading to a religiously experienced meaning. After all symbol is an embodiment of meaning, enabling humans to communicate, perpetuate and develop a vision of human life.

Symbol has the innate ability to make us feel 'at home' At the same time, by the same logic, it invites us to enter into the world of the symbols of the other and this is the mystery of, the dynamic of IRD, ushering in the gifts of different faiths that will serve as a reservoir of common pilgrimage - the reality of IRD.

A symbol is any reality that by its very dynamism or power leads to another deeper reality through a sharing in the dynamism that the symbol itself offers (and merely by verbal or additional explanations.)

A good many of the modern problems and conflicts, strangely though, have religions at their root, whether it is the Arab-Israel conflict, conflicts in the Middle East and Syria, the Kashmir problem, Indonesian conflicts, the conflicts in the southern Philippines and many others. In theory, practically all religions have the inbuilt theological underpinning for mutual understanding and collaboration. The belief in the antaryamin in Hinduism, i.e., the Divine indwells in all human beings, the Islamic vision of all humans by nature making a self-surrender to God, the Buddhist teaching of universal compassion, the Christian call to love and care for the neighbour, the basic understanding of harmony in the Chinese and Confucian religions, the understanding of Yahweh, the creator of all and as the Lord of History in Judaism, the vision of the salvation of the universe as understood by the primal religions, are all inviting the religions to come closer and to collaborate, rather than to compete and combat with each other. The right relationship with the neighbor is the focus of all religions. This is the challenge of Inter Religious Dialogue. Christians in particular, by their call to witness to the coming of the divine reign in Jesus Christ are called to IRD.

Prophet Isaiah's vision, 6:1-8, reminds us how our history, our experience of God, does not begin with us. The history of all people of God is part of our intimate relationship with God. "All the earth is filled with his glory" (Is 6:3). Isaiah's vision tells us also that no one, not even Isaiah or Moses, can have a total vision of the divine and this is an invitation for the religions to touch the Holy as experienced in the other, to be enriched by the other. God's dialogue with humans does not begin with any particular religion but with the creation. The bible insists also on a universal covenant of God with humans (Genesis 9:9-17).

This is a challenge for all followers of the different religious traditions to look into what we have in common rather than what differentiates us. It has to be acknowledged how all religions advocate peace, love, unity and tolerance, which in the past, due to narrow missionary zeal, was overlooked. Equally, it is a call not to compare religions to establish one's own superiority. What is important is to realize how each religion has a particular service to render to humanity, and ask how together we can usher in a superior quality of human existence.

Already the Old Testament paves the way for inter religious understanding leading to enrichment of one's religion. The Babylonian exile paved the way for the exiles to come into contact with the leading religion of the Babylonian world, Zoroastrianism and to be enriched by it, in the understanding of the only God - we come across strict monotheism in the Bible only towards the end of the exile (Isaiah 45: 18) though there was already the monolatry. The Zoroastrian understanding of the two ages served as the theological underpinning of the belief in the idea of resurrection of the dead. Sean Freyne writes: "The doctrine of the two ages is the theological underpinning for the belief in the idea of the resurrection of the dead - a doctrine that finds its first unequivocal expression in Daniel: 12:2-3" (1983:95). Judaism's adaptation to a life without the temple through the new institution of the synagogue, too, is resulting from the Zoroastrians who did not have one central temple but a temple where a community existed. ${ }^{\text {iv }}$

In the gospels, as we have seen already, Jesus is not an advocate of a religion as much as the quality of life, based on love and mercy. The early Christians were quite creative in their openness and sensitivity to the religious world of the times manifested in doing away with circumcision, in the theological interpretation of Jesus as the Lord than as the Christ/Messiah, and similar theological and practical developments.

\section{Christian Service}

The Christian call stands in continuity with the call of Israel, as a chosen people ... to serve humanity as a kingly, priestly and holy nation (Exodus 19: 6), that was repeated by Jesus in his sermon on the mount by reminding the community of his disciples that they are to serve the world as its light (Mt 5:14) and salt (Mt 5:13) (see also1 Peter 2:9). The Christian community is the continuation of the ministry of the Incarnate Word (Jn 20:21) who creates and enlightens all humans coming into the world (Jn 1:1-4, 9). The Christian community is aware, on the one hand, of the presence of the divine in all humans, on the other, at the same time, it realizes how it has a service to render to humanity, 
as the sacrament of the divine reign. Today this can be realized primarily, not exclusively, through IRD. To quote Jurgen Moltmann, "The church's abiding origin in Israel, its permanent orientation to Israel's hope, Christianity's resulting special vocation to prepare the way for the coming kingdom in history - all this will also give its stamp to the dialogue with the world religions" (1977:150).

Even as Jesus was anointed by the spirit to bring the good news to the poor, so also the Christian call is to be an agent of the good news to the poor (Mk 3:14-15; Lk 24:48-49; Mt 5:13-15 and Jn 20:21). What is required is a return to Jesus' own (God's own) priorities. This in today's world can be done only in collaboration with all. That is what makes IRD the fulcrum of church's service to the world today.

Scientists tell us how we have entered a new geological epoch, that of the Anthroposcene, i.e., human actions affecting the very metabolism of the planet postponing the next ice age at least by 50,000 years (BBC, 2016). This makes the care of the earth, as our very immediate neighbour, also very much part of the realization of the acceptable year of the Lord. Pope Francis made care of the earth a central concern of the Catholic Church and invites followers of all religions "to dialogue among themselves for the sake of protecting nature, defending the poor, and building networks of respect and fraternity. ... The gravity of the ecological crisis demands that we all look to the common good, embarking on a path of dialogue which demands patience, self-discipline and generosity, always keeping in mind that "realities are greater than ideas" (2015: n 201).

In IRD we work united in our common humanity and mutual responsibility, as well as in the shared values and convictions. In this Christians, as the expression of their service to the realization of the acceptable year of the Lord, can and must take the lead to foster a culture of human ecology that increasingly promotes harmony within individuals and in their relationships. The community of the disciples, the little flock (Lk 12:32), has to become the leaven and light in this movement of IR collaboration.

Christian commitment invites us to appreciate the fact that every culture and every religion is a manifestation of the divine love and goodness, though mixed also with human selfishness. It is here we see the significance of the healing mission of Jesus with his message of the Kingdom. Any local Christian community anywhere in the world must enter into dialogue with the local religions as the continuation of the Lord Jesus' ministry. This made the Evangelical churches to affirm in their October 2010 Cape Town Commitment: "In the name of the God of love, we repent of our failure to seek friendships with people of Muslim, Hindu, Buddhist and other religious backgrounds. In the spirit of Jesus, we will take initiatives to show love, goodwill and hospitality to them" (2011:72).

\section{Metaphysical Humility}

We Christians cannot play God or dictate terms to God by asking God to do "home work" (Kosuke Koyama), i.e., restrict God's salvation to those whom we recommend, but allow ourselves to be subject to God's plans. This requires a metaphysical humility that acknowledges our own limitations and the perfectibility of our religious tradition and our understanding of it, as well as the religious truth to which others respond prompted by the mystery of the same Word that became flesh (Jn 1:9). As Catherine Cornille has suggested, this humility is motivated also by "the recognition of the partial and finite nature of the ways in which ultimate truth has been grasped and expressed in the teachings and practices of one's own tradition" (2008: 10). Obviously, such humility demands the giving up of claims of ultimate and exclusive monopoly over truth and revelation in so far as it can only lead to interreligious conflicts and violence, not to speak of the fact that the bible does not always support such claims.

Raymond Panikkar has cautioned us of the need to have an ontological humility in interreligious dialogue in so far as dialogue reminds us of our temporality, our contingency, our constitutive limitation. "Humility is not primarily a moral virtue, but an ontological one; it is the awareness of the place of my ego, the truthfulness of accepting my real situation, namely, that I am a situated being, a vision's angle on the real of the real, an existence" (1999: 37). Such a metaphysical humility enabled mystics like Abhishiktananda and Bede Griffiths to be enriched by entering into the very soul of Hinduism. Abhishiktananda was the first Catholic Priest to sit at the feet of a Hindu guru making himself a disciple of Sri Ramana Maharsi. This enabled Abhishiktananda to realize that the great primitive Upananishads, like the Chandogya and Brihadaranyaka, are the incomparable witness to the awakening of the soul to the Mystery of being and of the self, and these earliest formulations of that experience have never been surpassed (Abhishiktananda, 1969: 51).

\section{Historical Consciousness}

Our history, the time in which we live, is not just a succession of events, a chronology, but it is very much part of God's plan for us, in which God acts. Thus, it is very much a Kairos, divine time (salvation history). Through our involvement in IRD we Christians are called to collaborate in the divine design to convert the chronos into Kairos. 
The late Pope John XXIII expressed this historical consciousness through his pointing out the need to have the ability to read "the signs of the times" (1961) which can be characterized as the ongoing divine revelation in history. The spring time of religious revival that we witness everywhere may be said to be a sign of the time in this sense and has to be taken seriously as long as it enables humans to grow in love and concern for each other.

All religions must build bridges among themselves based on the inter connection of the understanding of the ultimate Reality, despite the differences in the specific grasp and explanation of the same. Today scholars like David Tracy (2005) and Francis Clooney (2010) speak of comparative theology, i.e., theology developed not only on our own scriptures but also in the light of our reading of the scriptures of other religions. It underlines the need for thinking interreligiously, interpreting home tradition in critical correlation with other traditions.

Similarly, there has to be a certain amount of willingness to place oneself into the religious world of the other, not only intellectually by trying to understand the reality behind the religious symbols of the other, but also through an honest attempt to enter into the religious mind set of the other with a view to understand the other from within. Catherine Cornille expresses it well: "Even though religion is certainly more than a feeling, the affective dimension does play a crucial role in the religious life of any person, and a proper understanding of another religion would thus be seriously impoverished with access to the meaning of a particular belief or practice for the person involved" (2008:138). Religions would require empathy to enter into relationship and communion with one another.

\section{Witnessing to Jesus Christ}

Empathy for one another will lead the followers of religious traditions to a certain reciprocity in dialogue sharing their religious experience with an openness to understand each other's faith. It is here that the Christian will witness to Jesus Christ, making it clear that what makes the Christian be involved in Inter religious dialogue is precisely the response to Jesus' call to collaborate in ringing in the divine reign. This is a significant form of mission in the post-colonial era. Obviously, we can pray and hope that at least some, with whom we enter into dialogue, may be attracted to Jesus Christ and commit themselves to follow him in his ministry. At any rate, mission in the post-colonial world is not any more a one way traffic but a sharing of one's spiritual experience with others.

Dialogue generally presupposes a certain level of informational exchange and the growth of knowledge about the dialogue partner's faith. This in turn, can lead to some sort of mutual religious fecundation, reciprocal inspiration and transformation. Interreligious dialogue, thus, becomes the context of witnessing, open to various possibilities that are to be left to the receiver and to the divine inspiration. However, in interreligious dialogue there is no question of any one-sided prophetic mission, nor is interreligious dialogue as such aimed at winning the dialogue partner to one's own religion. However, the Christian partner enters into dialogue as part of his/her commitment to follow Jesus Christ in his mission of making God's presence concrete and tangible in the world (Mt. 1:23 Jn 12:45), by becoming other-centred and working for the wholeness of life for all, as Jesus did. Similarly, the World Council of Churches in its Guidelines on Dialogue (1979) asserts: "Dialogue, therefore, is a fundamental part of Christian service within community. In dialogue Christians actively respond to the command to "love God and your neighbour as yourself. As an expression of love engagement dialogue testifies to the love experienced in Christ" (n 18). What is required is a historicization of the call of the World Council of Churches as well as Vatican II. As Massimo Faggioli, an expert on Vatican II wrote: "One of the ever-growing and important elements of Vatican II is the practical implications of ressourcement and rapprochement"deepening" and "reaching out," "reconciliation by proximity" (2015:176).

Each religion has kerygmatic as well as mystical aspects though some religions may emphasise the one over the other (Nissen, 2013:190). Christianity is a combination of both these aspects especially as witnessed in the fourth gospel. God reveals to humans from outside calling for transformation. Christianity tries to live this call. Simultaneously, as Gerd Theissen has shown there is, particularly in the fourth gospel, with its claim for absoluteness with boundless love, there is the mystical tradition as well (see Nissen: 71). Theissen has emphasized how "this Gospel of love must be seen as the only thing which is absolute in religious dialogue" (Nissen:191).

\section{Concluding Remarks}

At its earliest stage Christian mission was a sharing of an experience (1Jn 1:1-4), without any reference to any fall or atonement. It continued in that spirit until the time of the emperor Constantine and the imperial conquests thereafter. Gradually mission becomes merged with political motives and this process reaches its climax during the colonial times when mission was understood exclusively as an engagement with the followers of other religions - mission ad gentes. Post colonialism brings the challenge to return to the original Kingdom-centred mission in collaboration with the followers of other religions - mission inter-Religiones. In this process the Christian community has to play a constructive and vital role due to their commitment to follow Jesus Christ through IRD. Apart from this proactive impulse to IRD, the Christian community has to ensure that it does not contribute in any way to the religious madness and violence fuelled by religious sentiments that one comes across in many parts of the world. As the Interreligious 
Consultation, jointly organized by the Pontifical Council for Interreligious Dialogue and the Office for Interreligious Relations and Dialogue of the World Council of Churches, May 12-16, 2006, stated: "All of us believe that religions should be a source of uniting and ennobling of humans. Religions, understood and practiced in the light of the core principles and ideals of each of our faiths, can be a reliable guide to meeting the many challenges before humankind."

\section{References}

Abhishiktananda, S. (1969). Hindu-Christian Meeting Point. Bangalore: CISRS.

Arbuckle, G. (2010). Culture, Inculturation, Theology. Collegeville, MI: Michael Glacier.

BBC. (2016). Science and Environment, http://BBC.com/news/science-environment-35307800.

Blackburn, W. R. (2012). The God who Makes himself Known: The missionary heart of the Book of Exodus. Downers Grove, Il: Inter Varsity Press.

Clooney, F. (2010). Comparative Theology: Deep Learning Across Religious Borders. West Sussexx, UK: Wiley Blackwell.

Cornille, C. (2008). The Impossibility of Interreligious Dialogue. New York, NY: The Crossroad Publishing Company.

Documents of Vatican II, New York, NY: Guild Press, 703-709.

Evangelical Churches. (2011). "The Cape Town Commitment: A Confession of Faith and a Call to Action." International Bulletin of Missionary Research, 35(2).

Francis. (2013). Evangelii Gaudium. Vatican: Vatican Press.

Francis. (2015). Address to the General Audience Wednesday. http://www.wa.vatican.va/Francesco/en/audences/2015/documents/pope-francesco_20151028_udienza-generale.Ht $\mathrm{ml}$.

Francis. (2015). Laudato Si. Vatican: Vatican Press.

Freyne, S. (1983). The world of the New Testament. Wilmington, Del: Michael Glazier.

John Paul II. (2001). "Message to Cardinal Cassidy." Pro Dialogo 106/1.

John XXIII. (1961). Apostolic Constitution “Humane Salutis”. December 25. See Walter M Abbott, (ed). 1966).

Massimo, F. (2015). A Council for the Global Church: Receiving Vatican II in History. Minneapolis, MN: Fortress Press.

Moltmann, J. (1977). The Church in the Power of the Spirit. London: SCM Press.

Nissen, J. (2013). The Gospel of John and the Religious Quest: Historical and Contemporary Perspectives. Eugene, Or: Pickwich Pubications.

Panikkar, R. Intra Religious Dialogue. New York, NY: Paulist Press.

Theissen, G. (1994). Lichtspuren. Predigten und Bibelarbeiten. Guetersloh: Kaiser.

Tracy, D. (2005). “Comparative Theology," Encyclopaedia of Religions, 13. Lindsy, J. ed., $2^{\text {nd }}$ edn. Detroit: Macmillan. 91, 25-34.

World Council of Churches. (1979). Guidelines on Dialogue with People of Living Faiths and Ideologies, Geneva: WCC.

World Council of Churches. (2006). Current Dialogue, 47. (http:// wcc-coc.org/wcc/what/interreligious/cd47-18.html.

\section{Notes}

${ }^{1}$ All the biblical references are taken from The Holy Bible. (Revised Standard Version). (1966). London: Catholic Truth Society.

${ }^{1}$ The Second Vatican Council (1962-1965) was a general assembly of all the Catholic Bishops, convened by the then Pope John XXIII and continued by his successor Pope Paul VI, to enable the Catholic Church to render its service to the contemporary world more effectively through the Church's openness to the world and its humanity with their religions, cultures and their socio-economic-political reality.

${ }^{1}$ Vatican II, Declaration on the Relationship of the Church to Non-Christian Religions (Nostra Aetate). 
1 Though one hardly come across scholarly literature stating that the synagogue worship rose due to the influence of Zoroastrianism, scholars like Martin A. Cohen do recognize how the synagogue originated during the Babylonian captivity in the $6^{\text {th }}$ century BCE (Cf. Martin A. Cohen. (1987). "Synagogue," The Encyclopaedia of Religions. Vol 14, New York, NY: McMillan, 1987: 209-218) and this in turn supports Freyne Sean's position that the Jewish synagogue came into being under the influence of Zoroastrianism (Sean. 1983, 96).

\section{(cc) $E Y$}

This work is licensed under a Creative Commons Attribution 3.0 License. 